Check for updates

Cite this: RSC Adv., 2017, 7, 22017

\title{
Promotional effect of Ti doping on the ketonization of acetic acid over a $\mathrm{CeO}_{2}$ catalyst $\uparrow$
}

\author{
Feipeng Lu, ${ }^{a}$ BinBo Jiang, ${ }^{\text {*a }}$ Jingdai Wang, ${ }^{a}$ Zhengliang Huang, ${ }^{a}$ Zuwei Liao, ${ }^{a}$ \\ Yongrong Yang ${ }^{a}$ and Jie Zheng*b
}

A series of $\mathrm{Ce}_{1-x} \mathrm{Ti}_{x} \mathrm{O}_{2-\delta}$ mixed oxide catalysts were synthesized using a homogeneous precipitation method and characterized, and then these catalysts were applied to convert acetic acid to acetone using a gas-phase ketonization reaction. Ti-doped $\mathrm{Ce}_{1-x} \mathrm{Ti}_{x} \mathrm{O}_{2-\delta}$ catalysts $(x=0.1-0.5)$ exhibited much better ketonization performance than their parent catalysts of $\mathrm{CeO}_{2}$ and $\mathrm{TiO}_{2}$, and such Ti-doping-induced catalysis improvement is attributed to the formation of a $\mathrm{Ce}-\mathrm{O}-\mathrm{Ti}$ structure depending on the $\mathrm{Ti}$ content. Among the different $\mathrm{Ce}_{1-x} \mathrm{Ti}_{x} \mathrm{O}_{2-\delta}$ catalysts, the $\mathrm{Ce}_{0.7} \mathrm{Ti}_{0.3} \mathrm{O}_{2-\delta}$ catalyst calcinated at $500{ }^{\circ} \mathrm{C}$ showed the best catalysis activity and high stability. A combination of techniques (i.e. TEM, FTIR, $\mathrm{H}_{2}-\mathrm{TPR}$, $\mathrm{NH}_{3} / \mathrm{CO}_{2}$-TPD and XPS) further revealed that the formation of the $\mathrm{Ce}-\mathrm{O}-\mathrm{Ti}$ structure modified the surface acid-base properties and thus enhanced the redox properties. Moreover, the introduction of $\mathrm{Ti}$ into $\mathrm{CeO}_{2}$ also increased the number of oxygen vacancies on the catalysts' surface that favored the ketonization of acid molecules. This work provides valuable insights into the design of highly efficient $\mathrm{CeO}_{2}$-based catalysts for acid removal in the upgrading process of bio-oil.

Received 13th January 2017
Accepted 10th March 2017

DOI: $10.1039 / \mathrm{c} 7 \mathrm{ra00521k}$

rsc.li/rsc-advances bio-oil and yield abundant ketones with different increased lengths of carbons. The obtained ketones can be further upgraded into liquid fuels by the aldol condensation and hydrodeoxygenation process.

$$
2 \mathrm{RCOOH} \rightarrow \mathrm{R}_{2} \mathrm{CO}+\mathrm{CO}_{2}+\mathrm{H}_{2} \mathrm{O}
$$

Significant efforts have been made to develop different materials as catalysts for ketonization. Among them, metal oxides are considered as the most suitable and efficient ones due to their acid-base and redox properties. Based on different catalysis mechanisms, these metal oxides can be classified into two categories. ${ }^{2}$ The first category includes alkali and alkaline earth oxides with low lattice energies, which can catalyze the decarboxylation by decomposition of the corresponding carboxylate salts. These oxides are known as bulk ketonization catalysts. The second category includes $\mathrm{CeO}_{2}, \mathrm{MnO}_{2}, \mathrm{TiO}_{2}, \mathrm{ZrO}_{2}$, and others with higher lattice energies. These oxides can form surface intermediates including $\beta$-ketoacids, ketene etc., and are thus defined as surface ketonization catalysts. Moreover, compared with pure acidic or basic oxides, the amphoteric oxides, especially ceria-based catalysts, usually possess excellent ketonization activity and selectivity. Different ceria-based catalysts such as $\mathrm{CeO}_{2}-\mathrm{Fe}_{2} \mathrm{O}_{3},{ }^{3,4} \mathrm{CeO}_{2}-\mathrm{Mn}_{2} \mathrm{O}_{3},{ }^{3,5,6}$ and $\mathrm{CeO}_{2}-\mathrm{ZrO}_{2}$ (ref. 5, 7-12) have been developed for ketonization of carboxylic acids, and the activity of these ketonization reactions was largely improved by the modified $\mathrm{CeO}_{2}$ oxides. Since $\mathrm{CeZrO}_{x}$ catalysts exhibit outstanding reducibility and oxygen storage capacity, they are often used as preferable catalysts for the
${ }^{a}$ State Key Laboratory of Chemical Engineering, College of Chemical and Biological Engineering, Zhejiang University, Hangzhou 310027, P. R. China. E-mail: jiangbb@ zju.edu.cn

${ }^{b}$ Department of Chemical and Biomolecular Engineering, The University of Akron, Akron, Ohio, USA 44325

$\dagger$ Electronic supplementary information (ESI) available. See DOI: $10.1039 / \mathrm{c} 7 \mathrm{ra00521k}$ 
ketonization of carbohydrate-derived carboxylic acids and help to improve the catalytic activity of the ketonization reaction compared with other catalysts. It is generally believed that the excellent performance of $\mathrm{CeZrO}_{x}$ catalysts is attributed to the Lewis acid-base site pairs and the enhanced reducibility. ${ }^{\mathbf{1 0}}$ However, the structure-property-activity relationship of $\mathrm{CeO}_{2}$ based catalysts between ketonization activity, surface acid-base and redox characteristics, and structure of active composites still remains unclear, which hinders the development of applicable catalysts for the ketonization reaction.

In this work, we synthesized and characterized a series of Ce-Ti composite oxides using a homogeneous precipitation method, and then used them to catalyze the ketonization of acetic acid in the gas phase. Ce-Ti mixed oxides have been mainly used as catalysts for selective catalytic reduction (SCR) of $\mathrm{NO}_{x}$, while $\mathrm{TiO}_{2}$-anatase is the most commonly used supporting material for SCR catalysts that offers excellent dispersion of active components. ${ }^{13-15}$ The $\mathrm{Ti}^{4+}$ cations regarded as samevalence dopants to $\mathrm{CeO}_{2}$ could actually affect the properties of the host oxide, especially the redox properties. ${ }^{16}$ Furthermore, the modification of acid-base sites can also be obtained for Tidoped $\mathrm{CeO}_{2}$, which is caused by the introduction of both $\mathrm{Ti}^{4+}$ (Lewis acid) and $\mathrm{O}^{2-}$ (Lewis base) ions. ${ }^{17}$ However, to our knowledge, Ce-Ti composite oxides have not been reported as solid acid-base catalysts for acid ketonization to date. Herein, the ketonization process on Ce-Ti mixed oxides was examined to illustrate the relationship between surface structures and properties of Ce-Ti composite oxides and their catalytic activities. In addition, synergistic effects of the catalysts' acid-base sites and reducibility on the catalytic activity of $\mathrm{Ce}-\mathrm{Ti}$ mixed oxides were also studied using $\mathrm{NH}_{3} / \mathrm{CO}_{2}$-TPD and $\mathrm{H}_{2}$-TPR.

\section{Material and methods}

\subsection{Catalyst preparation}

A homogeneous precipitation method was adopted to prepare the $\mathrm{Ce}_{1-x} \mathrm{Ti}_{x} \mathrm{O}_{2-\delta}$ mixed oxide catalysts, where $x$ means the molar ratio of Ti. In a typical procedure, appropriate amounts of $\mathrm{Ti}\left(\mathrm{SO}_{4}\right)_{2}$ and $\mathrm{Ce}\left(\mathrm{NO}_{3}\right)_{3} \cdot 6 \mathrm{H}_{2} \mathrm{O}$ were dissolved in deionized water under vigorous stirring conditions until the formation of a clear solution. Excess urea solution was then added into the mixed solution, with a urea/(Ce $+\mathrm{Ti})$ molar ratio of $23: 1$. The solution was heated to $90{ }^{\circ} \mathrm{C}$ and held for $5 \mathrm{~h}$ with continuous stirring. The obtained yellow precipitate was decanted, filtered off, and washed with distilled water multiple times to remove the weakly adhered ions on the sample surface, followed by oven drying at $120{ }^{\circ} \mathrm{C}$ for $12 \mathrm{~h}$. Subsequently the oven-dried sample was calcined at a certain temperature $\left(400,500,650,800{ }^{\circ} \mathrm{C}\right)$ for $5 \mathrm{~h}$ in air at a heating rate of $5{ }^{\circ} \mathrm{C} \min ^{-1}$. Pure $\mathrm{CeO}_{2}$ and $\mathrm{TiO}_{2}$ were also prepared for comparison purposes by adopting the same method.

\subsection{Catalyst characterization}

The powder X-ray diffraction (XRD) patterns of the samples were recorded on a Philips PW3050/60 vertical goniometer using Nifiltered $\mathrm{Cu} \mathrm{K} \alpha 1$ radiation $(\lambda=1.5406 \AA)$. A proportional counter and a $0.02^{\circ}$ step size in the $2 \theta$ range from 20 to $80^{\circ}$ were used. The assignment of the various crystalline phases is based on the JPDS powder diffraction file cards. The crystal size of the prepared oxide was calculated using the Scherrer equation:

$$
L=\frac{K \lambda}{B \cos \theta}
$$

where $L$ is the crystallite size in $\mathrm{nm}, \lambda$ is the wavelength of the $\mathrm{X}$ ray radiation, $K$ is a dimensionless shape factor and usually taken as $0.89, \theta$ is the Bragg diffraction angle, $B$ is the line broadening at half the maximum intensity (FWHM), after subtracting the instrumental line broadening, in radians.

Raman spectra were recorded on a Thermo Scientific DXR Raman microscope with a He-Cd laser of excitation wavelength $532 \mathrm{~nm}$.

The BET surface area, pore volume, and pore size distribution measurements were performed using a Quantachrome Autosorb-iQ instrument. Prior to analysis, the samples were degassed at $300{ }^{\circ} \mathrm{C}$ for $3 \mathrm{~h}$ to remove any residual moisture. The BET surface areas were calculated from adsorption data in the relative pressure $\left(P / P_{0}\right)$ range of $0.04-0.25$. Pore size and pore volume were calculated using the BJH method applied to the desorption leg of the isotherms.

Temperature programmed reductions (TPR) were recorded using a thermal conductivity detector (TCD) and a reducing gas

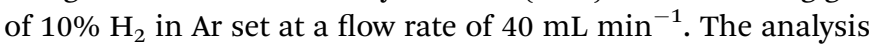
regime was as follows. Approximately $50 \mathrm{mg}$ samples were pretreated at $450{ }^{\circ} \mathrm{C}$ for $60 \mathrm{~min}$, the sample cell was purged with $\mathrm{a}_{2} / \mathrm{Ar}$ mixture for $30 \mathrm{~min}$ and the analysis run from $50{ }^{\circ} \mathrm{C}$ to $800{ }^{\circ} \mathrm{C}$ at a heating rate of $10{ }^{\circ} \mathrm{C} \mathrm{min}^{-1}$. Water produced by the reduction was trapped in an ice bath upstream of the TCD. $\mathrm{H}_{2}$ consumption was quantified by comparison to the reduction of CuO.

X-ray photoelectron spectroscopy (XPS) measurements were performed using an Escalab 250Xi with a monochromatized $\mathrm{Al}$ K source $(1486 \mathrm{eV})$. Narrow spectra were collected with a pass energy of $30 \mathrm{eV}$. The charge correction was made considering that the $\mathrm{C} 1 \mathrm{~s}$ signal of contaminating carbon $(\mathrm{C}-\mathrm{C}$ or $\mathrm{C}-\mathrm{H}$ bonds) was centered at $284.8 \mathrm{eV}$. The $\mathrm{C} 1 \mathrm{~s}$, Ti $3 \mathrm{~d}$, Ce $3 \mathrm{~d}$, and $\mathrm{O} 1 \mathrm{~s}$ levels were chosen for characterization because their signals are the most intense and do not overlap.

A Fourier transform IR spectrometer (NICOLET 5700, USA) was used to acquire the IR spectra of the samples. For the transmission FTIR, each disc was mixed with $1 \mathrm{wt} \%$ sample and $99 \mathrm{wt} \% \mathrm{KBr}$.

The nature and concentration of acid-base sites were studied by means of TPD of pre-adsorbed $\mathrm{NH}_{3} / \mathrm{CO}_{2}$ and the desorbed $\mathrm{NH}_{3} / \mathrm{CO}_{2}$ on a Quantachrome Instrument. Samples of approximately $100 \mathrm{mg}$ were outgassed and dried at $450{ }^{\circ} \mathrm{C}$ for

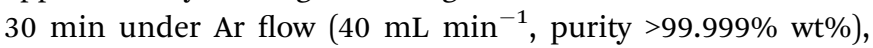
cooled to room temperature, and then treated with a flow of 10 vol\% $\mathrm{NH}_{3} / \mathrm{He}$ or $10 \%$ vol\% $\mathrm{CO}_{2} / \mathrm{Ar}\left(40 \mathrm{~mL} \mathrm{~min}^{-1}\right)$ for $120 \mathrm{~min}$. The sample cell was then evacuated for $20 \mathrm{~min}$ and a He flow at $40 \mathrm{~mL} \mathrm{~min}^{-1}$ was started. This continued for $15 \mathrm{~min}$ prior to the start of data collection. The sample was heated from room temperature to $500{ }^{\circ} \mathrm{C}$ at $10{ }^{\circ} \mathrm{C} \min ^{-1} . \mathrm{NH}_{3} / \mathrm{CO}_{2}$ was quantified 
by comparing the areas under the curve with the sample of known amounts of $\mathrm{NH}_{3} / \mathrm{CO}_{2}$ using thermal conductivity.

\subsection{Catalyst tests}

The gas-phase ketonization of carboxylic acids was carried out in a down-flow quartz fixed-bed reactor ( $9 \mathrm{~mm}$ i.d.) under atmospheric pressure. The temperature of heating furnace externally was measured using a K-type thermocouple attached to the reactor and controlled with a 708P temperature controller (Yudian Automation Technology Co., Ltd). A HPLC pump was used to introduce the liquid feed solution into the reactor. The ketonization reaction was operated in the temperature range of $250{ }^{\circ} \mathrm{C}$ to $350{ }^{\circ} \mathrm{C}$. Typically, $0.5 \mathrm{~g}$ of the as-prepared catalyst (4060 mesh) was placed in the middle region of the reactor between two plugs of quartz wool and fused $\mathrm{SiO}_{2}$ granules and the reaction was carried out at a liquid acetic acid flow rate of $3 \mathrm{~mL}$

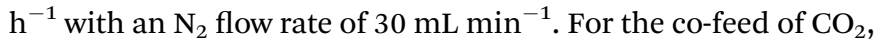
the total molar flow of the gas feed through the reactor was kept constant by modifying the molar ratio of $\mathrm{CO}_{2}$ and $\mathrm{N}_{2}$. For the $\mathrm{H}_{2} \mathrm{O}$ co-feeding experiment, the weight hourly space velocity (WHSV) of acetic acid was kept the same by adjusting the pump rate of $\mathrm{H}_{2} \mathrm{O}$ and the $\mathrm{N}_{2}$ flow rate. The mass transfer limitation was excluded during the tests.

The feed and gas-phase reaction mixtures were analyzed with online GC analysis equipped with two columns in parallel and two detectors to obtain reactant conversion and product selectivity. The outlet line was heated to $150{ }^{\circ} \mathrm{C}$ along with the injection valve of the gas chromatograph to avoid product condensation. For organic compounds, a FFAP capillary column $(30 \mathrm{~m} \times 0.32 \mathrm{~mm} \times 0.5 \mu \mathrm{m})$ was connected to a flame ionization detector, while for gas products, a TDX-01 column was connected to a TCD detector. Prior to the catalytic test, each sample was pretreated under a nitrogen flow at the lowest reaction temperature in the stream of reactant for $2 \mathrm{~h}$. The selectivity was defined as the percentage of carboxylic acid converted into a particular product taking into account the reaction stoichiometry; thus, $100 \%$ ketone selectivity would mean $1 \mathrm{~mol}$ of carboxylic acid converted to form 0.5 mole of the ketone. The mean absolute percentage error in conversion and selectivity was $\leq 10 \%$ and the carbon balance was maintained in the range of $100 \pm 5 \%$.

In the absence of catalyst, no conversion of acetic acid was observed. However, when $\mathrm{SiO}_{2}$ granules were used, a background conversion of $2-3 \%$ was detected for our typical reaction condition.

\section{Results and discussion}

\section{1 $\mathrm{Ce}_{1-x} \mathrm{Ti}_{x} \mathrm{O}_{2-\delta}$ catalyst performance}

The catalytic ketonization of acetic acid with the $\mathrm{Ce}_{1-x} \mathrm{Ti}_{x} \mathrm{O}_{2-\delta}$ catalysts was obtained at $280-350{ }^{\circ} \mathrm{C}$. As shown in Fig. $1 \mathrm{~A}$, the introduction of $\mathrm{Ti}$ atoms into $\mathrm{CeO}_{2}$ can promote the ketonization of acetic acid. The catalytic activity increased as the added amount of $\mathrm{TiO}_{2}$ into $\mathrm{CeO}_{2}$ was increased from $x=0.1$ to 0.3, with $\mathrm{Ce}_{0.7} \mathrm{Ti}_{0.3} \mathrm{O}_{2-\delta}$ catalyst reaching the highest conversion of $100 \%$. But, as the amount of $\mathrm{TiO}_{2}$ was further increased to $x=$
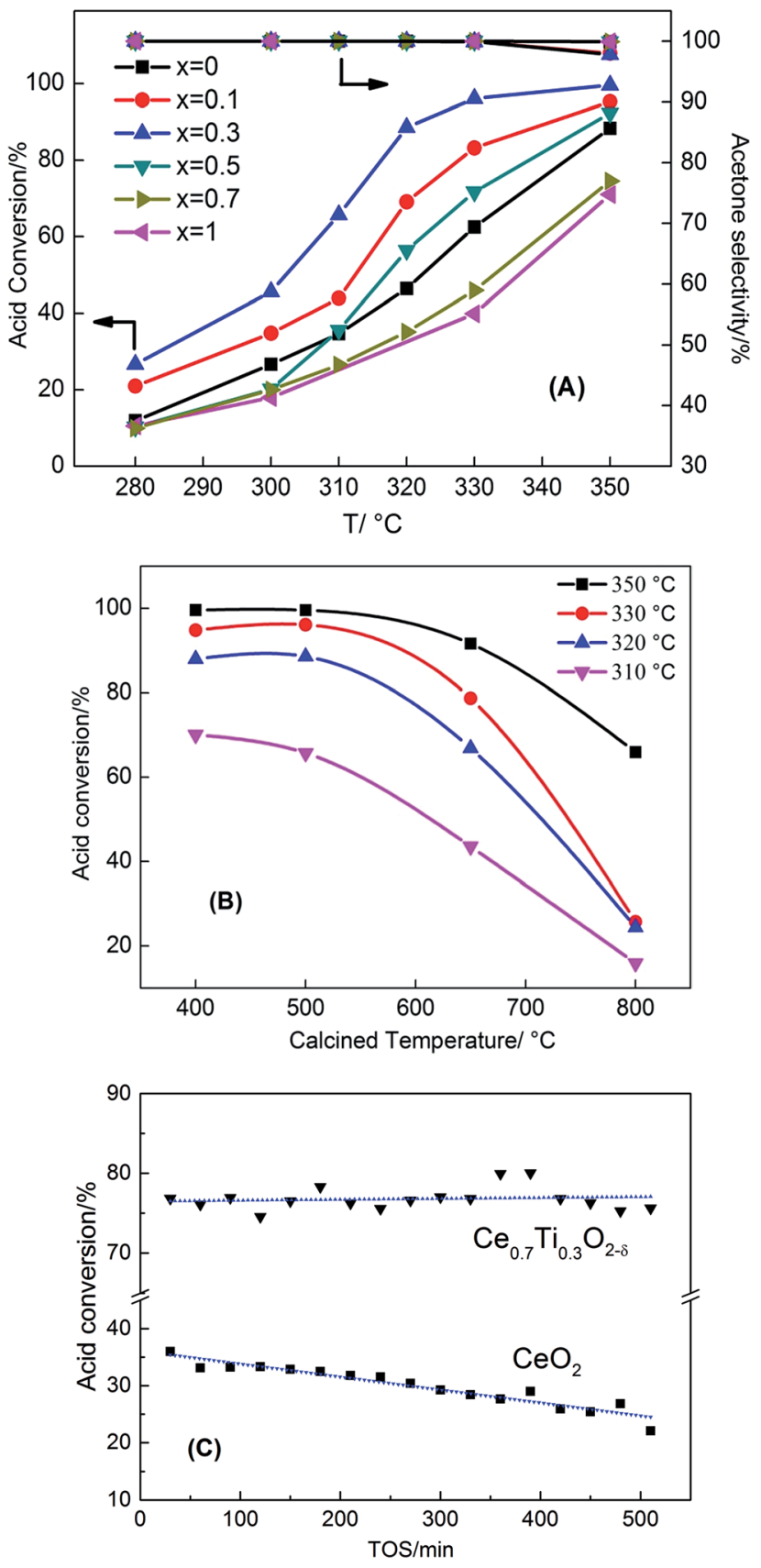

Fig. 1 Acetic acid conversion as a function of temperature for $(A)$ $\mathrm{Ce}_{1-x} \mathrm{Ti}_{x} \mathrm{O}_{2-\delta}$ catalysts and (B) $\mathrm{Ce}_{0.7} \mathrm{Ti}_{0.3} \mathrm{O}_{2-\delta}$ catalysts calcined at different temperatures, (C) acetic acid conversion of $\mathrm{Ce}_{0.7} \mathrm{Ti}_{0.3} \mathrm{O}_{2-\delta}$ and pure $\mathrm{CeO}_{2}$ at $315{ }^{\circ} \mathrm{C}$ as a function of time on stream (reaction

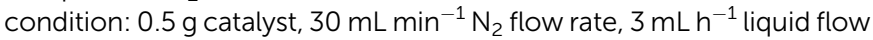
rate).

0.5, the catalytic activity decreased. Pure $\mathrm{TiO}_{2}$ showed a poor catalytic reaction of acetic acid ketonization compared with $\mathrm{CeO}_{2}$ when the reaction temperature was below $350{ }^{\circ} \mathrm{C}$. As one of the ketonization products, the $\mathrm{CO}_{2}$ formation rates at different ratios of $\mathrm{Ce} / \mathrm{Ti}$ are shown in Fig. $\mathrm{S} 1 . \dagger \mathrm{Ce}_{0.7} \mathrm{Ti}_{0.3} \mathrm{O}_{2-\delta}$ catalyst displayed the highest $\mathrm{CO}_{2}$ formation rate $(0.12 \mathrm{~mol}$ $\mathrm{h}^{-1}$ ), consistent with acid conversion data (Fig. 1A). In addition, other side-products (e.g. acetic anhydride, $\mathrm{CH}_{4}$, etc. ) produced at 
$350{ }^{\circ} \mathrm{C}$ had very low selectivity of $<2 \%$. The performance of the $\mathrm{Ce}_{0.7} \mathrm{Ti}_{0.3} \mathrm{O}_{2-\delta}$ catalyst was also compared with the results of other active metal oxides in the representative literature, and the results are shown in Table $\mathrm{S} 1 . \dagger$ It can be seen that $\mathrm{Ce}_{0.7^{-}}$ $\mathrm{Ti}_{0.3} \mathrm{O}_{2-\delta}$ catalyst is superior to those catalysts reported previously under similar reaction conditions.

Fig. 1B shows the influence of calcination temperature on the catalytic performance of the ketonization reaction. The $\mathrm{Ce}_{0.7} \mathrm{Ti}_{0.3} \mathrm{O}_{2-\delta}$ catalyst was selected for the ketonization reaction because of its excellent activity. It can be seen that $\mathrm{Ce}_{0.7} \mathrm{Ti}_{0.3} \mathrm{O}_{2-\delta}$ catalysts calcined at $400{ }^{\circ} \mathrm{C}$ and $500{ }^{\circ} \mathrm{C}$ displayed almost the same ketonization activity. At a calcined temperature of $650{ }^{\circ} \mathrm{C}$, the conversion of acetic acid reacted at $350{ }^{\circ} \mathrm{C}$ decreased from $100 \%$ to $91 \%$. When the calcined temperature further increased to $800{ }^{\circ} \mathrm{C}$, the reaction activity dropped drastically, leading to $66 \%$ conversion at $350{ }^{\circ} \mathrm{C}$. These results indicate that calcination temperature has a significant impact on acid conversion and ketone yield. Furthermore, regarding the stability of $\mathrm{Ce}_{0.7^{-}}$ $\mathrm{Ti}_{0.3} \mathrm{O}_{2-\delta}$ catalyst, Fig. $1 \mathrm{C}$ shows that the Ti-doped catalyst exhibited very high stability to retain a higher acid conversion of $75 \%$ for $500 \mathrm{~min}$. In sharp contrast, $\mathrm{CeO}_{2}$ deactivated rapidly from $36 \%$ to $22 \%$ within 500 min.

\subsection{Catalyst characterization}

3.2.1 Physical properties of $\mathrm{Ce} / \mathrm{Ti}$ mixed oxide catalysts. Fig. 2A shows the XRD patterns of various $\mathrm{Ce}_{1-x} \mathrm{Ti}_{x} \mathrm{O}_{2-\delta}$ mixed oxides calcined at $500{ }^{\circ} \mathrm{C}$ for $5 \mathrm{~h}$. Pure $\mathrm{CeO}_{2}$ and $\mathrm{TiO}_{2}$ displayed the pure cubic fluorite phase (PDF 00-0065-5923) and anatase phase (PDF 00-021-1272) structure, respectively. Only a cubic phase was observed in the $\mathrm{Ce}_{1-x} \mathrm{Ti}_{x} \mathrm{O}_{2-\delta}$ samples when $x<0.5$, suggesting that a small addition of $\mathrm{TiO}_{2}$ to $\mathrm{CeO}_{2}$ causes the formation of a $\mathrm{CeO}_{2}$-like solid solution. The $\mathrm{CeO}_{2}$ (111) peak shifts to higher angles with the increasing amount of doping $\mathrm{Ti}$ (shown in the inset) and this was attributed to the lattice contraction caused by the smaller size of doping $\mathrm{Ti}^{4+}$ ions $(0.068$

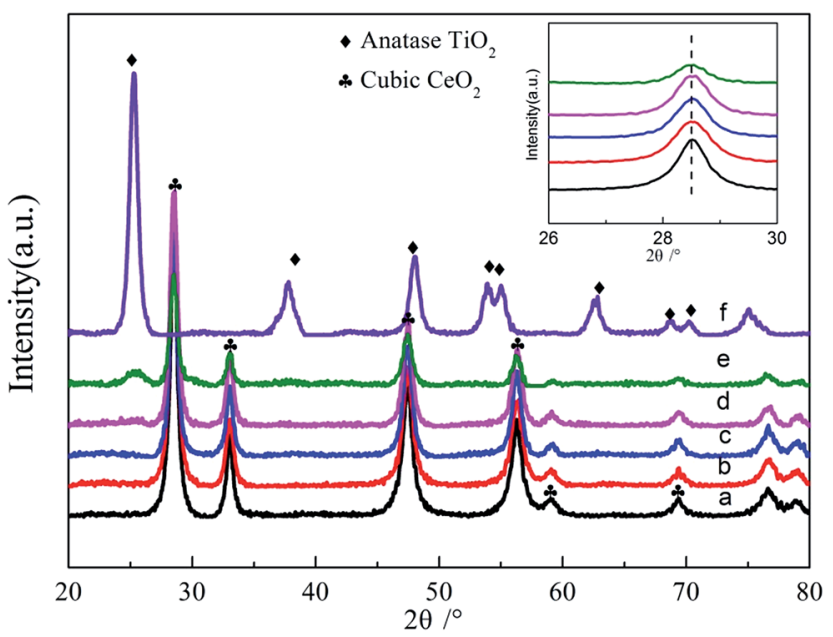

Fig. 2 XRD patterns of as-prepared $\mathrm{Ce}_{1-x} \mathrm{Ti}_{x} \mathrm{O}_{2-\delta}$ catalysts: (a) $x=0$, (b) $x=0.1$, (c) $x=0.3$, (d) $x=0.5$, (e) $x=0.7$, (f) $x=1$. The inset shows the shifting of the $\mathrm{CeO}_{2}$ (111) peak to higher energies with increasing amount of doping $\mathrm{Ti}$. $\mathrm{nm})$ than the $\mathrm{Ce}^{4+}$ ion $(0.094 \mathrm{~nm})$. Correspondingly, the calculated lattice parameters listed in Table 1 decreased with increasing Ti content. A weak peak for the $\mathrm{Ce}_{0.5} \mathrm{Ti}_{0.5} \mathrm{O}_{2-\delta}$ sample occurred at a diffraction angle $(2 \theta)$ of $25.3^{\circ}$ in the $\mathrm{TiO}_{2}$ anatase phase, indicating a limited solubility of $\mathrm{TiO}_{2}$ in the ceria matrix. Moreover, the $\mathrm{Ce}_{0.3} \mathrm{Ti}_{0.7} \mathrm{O}_{2-\delta}$ sample showed a mixture of anatase $\mathrm{TiO}_{2}$ and cubic $\mathrm{CeO}_{2}$, and this suggests that the excess amount of doped Ti cannot enter the inside of the ceria lattice, and instead they concentrate on the surface.

Fig. S2 $\uparrow$ shows the $\mathrm{N}_{2}$ adsorption-desorption isotherms and corresponding pore size distributions of $\mathrm{Ce}_{1-x} \mathrm{Ti}_{x} \mathrm{O}_{2-\delta}$ mixed oxides, in comparison with those of pure $\mathrm{CeO}_{2}$ and $\mathrm{TiO}_{2}$. All isotherms displayed a type IV shape with a $\mathrm{H} 3$ hysteresis loop at high relative pressures of $0.4-1$, suggesting the presence of slitlike mesopores, associated with aggregates of plate-like particles. Table 1 summarizes the physical properties, crystalline structure, and crystallite size obtained from $\mathrm{N}_{2}$ adsorptiondesorption isotherms and XRD data. With the increasing amount of $\mathrm{Ti}$ being doped into $\mathrm{CeO}_{2}$, the surface area increased gradually from $81.5 \mathrm{~m}^{2} \mathrm{~g}^{-1}$ to $93.7 \mathrm{~m}^{2} \mathrm{~g}^{-1}$ and the crystallite size increased from $11.1 \mathrm{~nm}$ to $13.1 \mathrm{~nm}$, respectively. From the calculated crystallite sizes of $\mathrm{Ce}_{1-x} \mathrm{Ti}_{x} \mathrm{O}_{2}$ catalysts in Table 1, $\mathrm{Ce}_{0.3} \mathrm{Ti}_{0.7} \mathrm{O}_{2-\delta}$ showed a relatively smaller crystallite size than pure $\mathrm{CeO}_{2}$, because of the appearance of the $\mathrm{TiO}_{2}$ anatase phase in $\mathrm{Ce}_{0.3} \mathrm{Ti}_{0.7} \mathrm{O}_{2-\delta}$, which restrained the growth of $\mathrm{CeO}_{2}$ crystal particles. The HRTEM micrographs and SAED images of $\mathrm{Ce}_{0.7^{-}}$ $\mathrm{Ti}_{0.3} \mathrm{O}_{2-\delta}$ sample are displayed in Fig. S3. $\dagger$ The TEM images show that the $\mathrm{Ce}_{0.7} \mathrm{Ti}_{0.3} \mathrm{O}_{2-\delta}$ sample is composed of nanosized particles with an average particle size of $\sim 11 \mathrm{~nm}$, coinciding with the results obtained from XRD patterns. The continuous rings in the SAED patterns (shown as the inset in Fig. S3†) confirm the high crystallinity and the fluorite structure of $\mathrm{Ce}_{0.7} \mathrm{Ti}_{0.3} \mathrm{O}_{2-\delta}$ sample.

Fig. 3 shows Raman spectra of various $\mathrm{Ce}_{1-x} \mathrm{Ti}_{x} \mathrm{O}_{2-\delta}$ catalysts. Pure $\mathrm{CeO}_{2}$ exhibited a prominent band at $c a .461 \mathrm{~cm}^{-1}$ corresponding to the $\mathrm{F}_{2 \mathrm{~g}}$ Raman active mode in metal dioxides with a fluorite-like structure. ${ }^{18}$ Three Raman bands at 391, 515, and $638 \mathrm{~cm}^{-1}$ were identified for pure anatase $\mathrm{TiO}_{2}$. The former two bands were assigned to the $\mathrm{B}_{1 \mathrm{~g}}$ mode, while the latter band was assigned to the $\mathrm{E}_{2 \mathrm{~g}}$ mode. ${ }^{19}$ Addition of Ti led to a gradual attenuation of the $\mathrm{F}_{2 \mathrm{~g}}$ band intensity, and this is likely caused by the decrease of $\mathrm{Ce}$ amount and different crystallite sizes of $\mathrm{CeO}_{2} \cdot \mathrm{Ce}_{1-x} \mathrm{Ti}_{x} \mathrm{O}_{2-\delta}$ samples at $x<0.5$ retained their sole $\mathrm{F}_{2 \mathrm{~g}}$ mode of $\mathrm{CeO}_{2}$ with the increasing amount of doped Ti, and this further confirms that the Ce-O-Ti linkage bonds are formed for $\mathrm{Ce}_{1-x} \mathrm{Ti}_{x} \mathrm{O}_{2-\delta}(x<0.5)$. The $\mathrm{Ce}_{0.5} \mathrm{Ti}_{0.5} \mathrm{O}_{2-\delta}$ catalyst showed slight Raman peaks of three modes $\left(391,515\right.$, and $\left.638 \mathrm{~cm}^{-1}\right)$ similar to anatase $\mathrm{TiO}_{2}$, while $\mathrm{Ce}_{0.3} \mathrm{Ti}_{0.7} \mathrm{O}_{2-\delta}$ showed distinct Raman lines characteristic of anatase $\mathrm{TiO}_{2}$ together with a large drop in $\mathrm{F}_{2 \mathrm{~g}}$ band intensity. Besides, the visible Raman spectroscopy employed in this work mainly supplies the bulk information of the catalysts. ${ }^{20,21}$ Hence, no related peak was observed in around $585 \mathrm{~cm}^{-1}$ (ref. 22) or $601 \mathrm{~cm}^{-1}$ (ref. 23) that were attributed to production of oxygen vacancies, indicating that the bulk oxygen vacancies might not be formed on these catalysts.

3.2.2 FTIR spectra of Ce/Ti mixed oxide catalysts. Fig. $\mathrm{S} 4 \dagger$ shows FTIR transmission spectra of the as-prepared Ce-Ti 
Table 1 Physical properties, crystalline structure and crystallite size of $\mathrm{Ce}_{1-x} \mathrm{Ti}_{x} \mathrm{O}_{2-\delta}$ catalysts

\begin{tabular}{|c|c|c|c|c|c|c|}
\hline Samples & $S_{\mathrm{BET}}\left(\mathrm{m}^{2} \mathrm{~g}^{-1}\right)$ & $\begin{array}{l}\text { Pore volume } \\
\left(\mathrm{cm}^{3} \mathrm{~g}^{-1}\right)\end{array}$ & $\begin{array}{l}\text { Pore diameter } \\
(\mathrm{nm})\end{array}$ & Crystallite structure & Lattice parameter $^{a}(\mathrm{~nm})$ & $\begin{array}{l}\text { Mean crystallite } \\
\text { size }(\mathrm{nm})\end{array}$ \\
\hline $\mathrm{CeO}_{2}$ & 117 & 0.129 & 3.71 & Cubic & 0.543 & $12.2^{b}$ \\
\hline $\mathrm{Ce}_{0.7} \mathrm{Ti}_{0.3} \mathrm{O}_{2-\delta}$ & 86 & 0.284 & 5.05 & Cubic & 0.541 & $12.4^{b}$ \\
\hline $\mathrm{Ce}_{0.5} \mathrm{Ti}_{0.5} \mathrm{O}_{2-\delta}$ & 94 & 0.204 & 4.74 & Cubic & 0.539 & $13.1^{b}$ \\
\hline $\mathrm{Ce}_{0.3} \mathrm{Ti}_{0.7} \mathrm{O}_{2-\delta}$ & 99 & 0.197 & 5.06 & Anatase + cubic & 0.538 & $5.1^{b}$ \\
\hline
\end{tabular}

${ }^{a}$ Estimated by the formulate $a=\left(h^{2}+k^{2}+l^{2}\right)^{1 / 2} \times(\lambda / 2 \sin \theta)$ using the $\{111\}$ lattice face. ${ }^{b}$ Determined by the main peak of CeO $\mathrm{Cubic}$ phase. ${ }^{c}$ Determined by the main peak of $\mathrm{TiO}_{2}$ anatase phase.

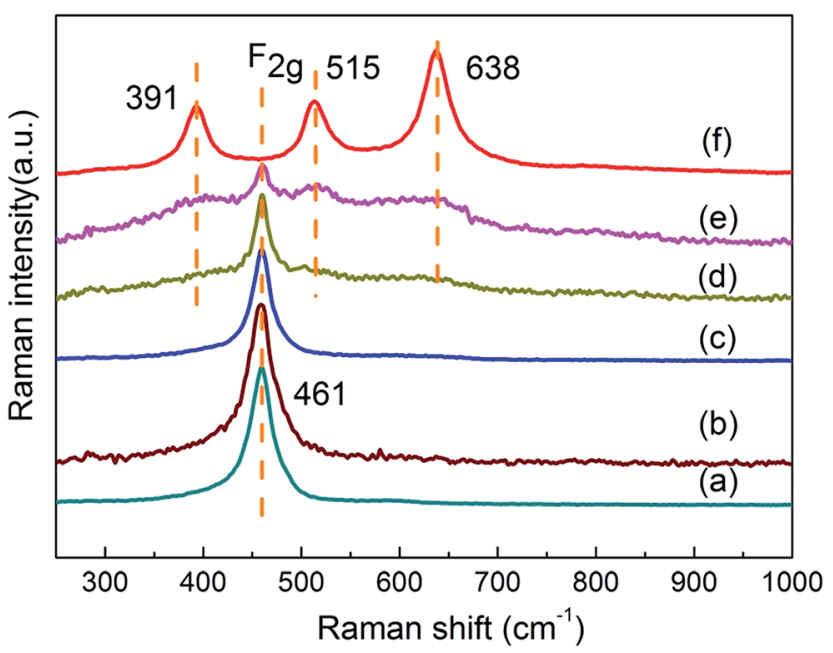

Fig. 3 Raman spectra of various $\mathrm{Ce}_{1-x} \mathrm{Ti}_{x} \mathrm{O}_{2-\delta}$ catalysts: (a) $x=0$, (b) $x=0.1$, (c) $x=0.3$, (d) $x=0.5$, (e) $x=0.7$, (f) $x=1$.

composite catalysts. The absorption peaks at $3400 \mathrm{~cm}^{-1}$ were attributed to the stretching vibration of $-\mathrm{OH}$ groups from the adsorbed water, while those peaks around $1600 \mathrm{~cm}^{-1}$ correspond to the bending vibrations of $-\mathrm{OH}$ groups on the surface of the catalysts. Pure $\mathrm{CeO}_{2}$ possessed a certain amount of surface $-\mathrm{OH}$, while $\mathrm{TiO}_{2}$ was short of surface -OH. Peaks below 883 $\mathrm{cm}^{-1}$ were ascribed to the $\nu(\mathrm{Ce}-\mathrm{O})$ or $\nu(\mathrm{Ti}-\mathrm{O})$ vibrational mode. The band at $1065 \mathrm{~cm}^{-1}$ for pure $\mathrm{CeO}_{2}$ was assigned to the bending vibrations of the hydroxyl group of metal oxides $(\mathrm{Ce}-$ $\mathrm{OH}) .^{24-26}$ The absence of peaks between $1250-1000 \mathrm{~cm}^{-1}$ for $\mathrm{TiO}_{2}$ could be due to the lack of surface hydroxylation. Doping Ti into $\mathrm{CeO}_{2}$ led to the peaks below $883 \mathrm{~cm}^{-1}$ moving towards the higher wavenumber region, as well as the formation of a new peak at $1120 \mathrm{~cm}^{-1}$. This indicates that a new surface linkage of Ce-O-Ti is formed ${ }^{15}$ and the appearance of the peak at $1120 \mathrm{~cm}^{-1}$ should be due to the hydroxyl groups linked to the surface Ce-O-Ti structure. ${ }^{27}$ When more Ti was doped into $\mathrm{CeO}_{2}(x>0.5)$, the mixed oxides became less able to produce more Ce-O-Ti bonds, thus the peak intensity at $1120 \mathrm{~cm}^{-1}$ dropped for the $\mathrm{Ce}_{0.3} \mathrm{Ti}_{0.7} \mathrm{O}_{2}$ sample. $\mathrm{Ce}-\mathrm{O}-\mathrm{Ti}$ bonds in the $\mathrm{Ce}_{0.3} \mathrm{Ti}_{0.7} \mathrm{O}_{2-\delta}$ sample were partially broken due to the appearance of pure $\mathrm{TiO}_{2}$ particles as evidenced by the XRD patterns in Fig. 2.
3.2.3 TPR profiles of $\mathrm{Ce} / \mathrm{Ti}$ mixed oxide catalysts. Fig. 4 shows the TPR profiles of the $\mathrm{Ce}_{1-x} \mathrm{Ti}_{x} \mathrm{O}_{2-\delta}$ catalysts. $\mathrm{H}_{2}-\mathrm{TPR}$ results were used to quantify the ability of ceria to be reduced, which is related to the properties of fluorite structured-mixed valence oxides to deviate from stoichiometry. ${ }^{28} \mathrm{CeO}_{2}$ is generally reduced in a stepwise way: first reduction of Ce(Iv) species on the surface $\mathrm{CeO}_{2}$, followed by the second reduction of bulk $\mathrm{CeO}_{2}$. Here, $\mathrm{CeO}_{2}$ showed a reduction peak at $504.4{ }^{\circ} \mathrm{C}$ due to the reduction of oxides on the surface..$^{18,28}$ In contrast with pure $\mathrm{CeO}_{2}$ oxide, pure $\mathrm{TiO}_{2}$ oxide is difficult to be reduced as evidenced by no obvious reduction peak from $50{ }^{\circ} \mathrm{C}$ to $800{ }^{\circ} \mathrm{C}$. The reduction properties of $\mathrm{Ce}_{1-x} \mathrm{Ti}_{x} \mathrm{O}_{2-\delta}$ catalysts are evidently enhanced by the introduction of $\mathrm{Ti}$ into the $\mathrm{CeO}_{2}$ lattice. As shown in Table $\mathrm{S} 2, \uparrow \mathrm{H}_{2}$ consumption of all $\mathrm{Ce}_{1-x} \mathrm{Ti}_{x} \mathrm{O}_{2-\delta}$ catalysts $(0.1<x<0.9)$ was much higher than that of pure $\mathrm{CeO}_{2}$ and $\mathrm{TiO}_{2}$, indicating that the doping $\mathrm{Ti}$ ions could weaken the $\mathrm{Ce}-\mathrm{O}$ bonds in the solid solution of Ce-Ti mixed oxides and the newly formed weakly bound oxygens should be responsible for the enhanced reducibility. ${ }^{29}$ Besides, the reduction peaks were obviously shifted to high temperatures for samples with high Ti content $(x \geq 0.5)$. This fact suggests that the introduction of abundant Ti will cause structure distortion and the breaking of Ce-O-Ti bonds as verified by XRD, Raman and FTIR results. This showed an opposite trend to the redox behavior of mixed oxides.

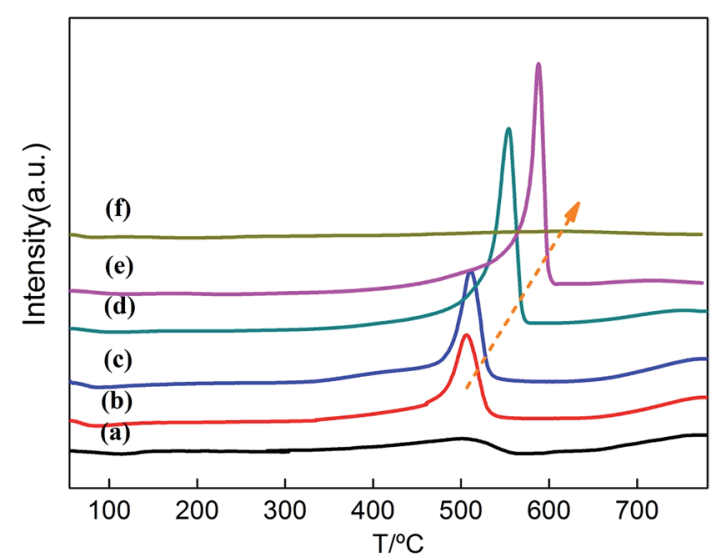

Fig. $4 \mathrm{H}_{2}$-TPR profiles of $\mathrm{Ce}_{1-x} \mathrm{Ti}_{x} \mathrm{O}_{2-\delta}$ catalysts at (a) $x=0$, (b) $x=0.1$, (c) $x=0.3$, (d) $x=0.5$, (e) $x=0.7$, (f) $x=1$. 

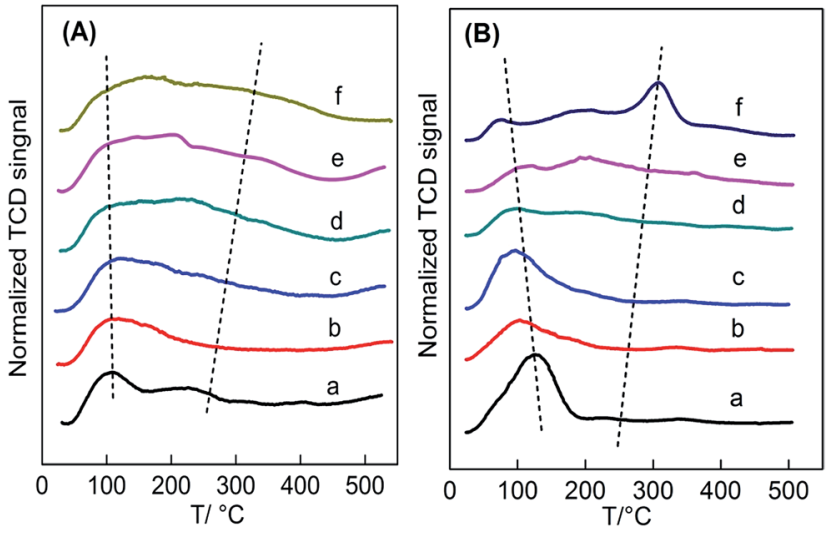

Fig. 5 (A) $\mathrm{NH}_{3}$-TPD and (B) $\mathrm{CO}_{2}$-TPD profiles of $\mathrm{Ce}_{1-x} \mathrm{Ti}_{x} \mathrm{O}_{2-\delta}$ catalysts at (a) $x=0$, (b) $x=0.1$, (c) $x=0.3$, (d) $x=0.5$, (e) $x=0.7$, (f) $x=1$.

3.2.4 $\mathrm{NH}_{3}-\mathrm{TPD} / \mathrm{CO}_{2}$-TPD of $\mathrm{Ce}-\mathrm{Ti}$ mixed oxides. Fig. $5 \mathrm{~A}$ shows $\mathrm{NH}_{3}$-TPD profiles of $\mathrm{Ce}_{1-x} \mathrm{Ti}_{x} \mathrm{O}_{2-\delta}$ catalysts. These desorption peaks were deconvoluted by the simple Gaussian function. Weak and strong acid sites were estimated from the desorption peak in the temperature range of $50-250{ }^{\circ} \mathrm{C}$ and $250-500{ }^{\circ} \mathrm{C}$, respectively (as shown by two dotted lines in Fig. 5), and these include both Brønsted and Lewis acidic sites. ${ }^{\mathbf{3 0 , 3 1}}$ Brønsted acid sites are assigned to surface $-\mathrm{OH}$ groups and the stronger Lewis acid sites are provided by coordinatively unsaturated surface metal cations $\left(\mathrm{M}^{3+}\right.$ or $\left.\mathrm{M}^{4+}\right) \cdot{ }^{32}$ It can be found that pure $\mathrm{CeO}_{2}$ mainly contained weak acid sites with a primary desorption peak at $\sim 100{ }^{\circ} \mathrm{C}$. As has been reported by other researchers, ${ }^{33}$ weak acid sites of $\mathrm{CeO}_{2}$ mainly represented the surface hydroxyl groups. Nevertheless, pure $\mathrm{TiO}_{2}$ contained both weak and strong acid sites while the latter ones dominated, corresponding to the high content of surface Lewis acidic sites. This finding is consistent with the previous results ${ }^{34}$ that $\mathrm{TiO}_{2}$ possesses the highest Lewis acid strength compared with $\mathrm{ZrO}_{2}$ and $\mathrm{CeO}_{2}$.

Fig. 5B presents the $\mathrm{CO}_{2}$-TPD profiles of the $\mathrm{Ce}_{1-x} \mathrm{Ti}_{x} \mathrm{O}_{2-\delta}$ catalysts. Similar to the $\mathrm{NH}_{3}$-TPD profiles, these profiles can be divided into two regions of weak adsorption sites $\left(50-250{ }^{\circ} \mathrm{C}\right)$ and strong adsorption sites $\left(250-500{ }^{\circ} \mathrm{C}\right)$ in a wide temperature range $\left(50-500{ }^{\circ} \mathrm{C}\right)$. Since $\mathrm{CeO}_{2}$ only had weak basic sites, ${ }^{33}$ desorbed $\mathrm{CO}_{2}$ was detected at a low temperature range. Weak basic sites in $\mathrm{CeO}_{2}$ lead to the formation of surface-OH groups because they act as both acidic and basic sites. Differently, the presence of strong basic sites in $\mathrm{TiO}_{2}$ caused $\mathrm{CO}_{2}$ to be desorbed at a high temperature range. In fact, there are two types of surface $-\mathrm{OH}$ groups due to various structures. ${ }^{35} \mathrm{CeO}_{2}$ hydroxyl groups are mainly nucleophilic groups that always serve as reactive basic $\left(\mathrm{O}^{2-}\right)$ sites, while $\mathrm{TiO}_{2}$ hydroxyl groups are essentially $\mathrm{H}$-bond donors. Thus, the two oxide catalysts expose variously structured surface-OHs, which may cause the discrepancy of $\mathrm{CO}_{2}$ adsorption on the oxide surface. It can also be seen that the low-temperature desorbed peak moved towards lower temperatures with increasing addition of $\mathrm{Ti}$, which could be attributed to the gradual formation of Ce-O-Ti linkages instead of $\mathrm{Ce}-\mathrm{O}-\mathrm{Ce}$ in $\mathrm{CeO}_{2}$.
The changes in the distribution and strength of surface acidbase sites versus Ti content were summarized in Table S3† and shown in Fig. 6a-d. The total surface density of Ce-Ti composite oxides gradually increased with amount of $\mathrm{Ti}$, while the density of strong acid sites on the surface increased almost linearly with Ti (Fig. 6c), further confirming that the addition of Ti can greatly enhance the strength of strong acids. In addition, the $\mathrm{Ce}_{0.7^{-}}$ $\mathrm{Ti}_{0.3} \mathrm{O}_{2-\delta}$ sample achieved a maximal value for the density of weak acid sites, while the $\mathrm{Ce}_{0.5} \mathrm{Ti}_{0.5} \mathrm{O}_{2-\delta}$ sample enabled the transformation of weak acid sites to strong acid sites. This could be attributed to $\mathrm{NH}_{3}$ adsorption on the strong Lewis acids provided by sufficiently doped $\mathrm{Ti}^{4+} \cdot{ }^{32,35}$ Due to the co-existence of both acid-base pairs in $\mathrm{TiO}_{2}$, the density of strong basic sites increased linearly with the added amount of Ti (Fig. 6d). On the other hand, this kind of strong basic site was not greatly enhanced by adding $\mathrm{TiO}_{2}$ until $x \geq 0.5$. In other words, $\mathrm{CeO}_{2}$ rich samples, which showed a typical $\mathrm{CeO}_{2}$ cubic phase in the XRD patterns, contained more weak acid-base sites compared with others. In the case of $\mathrm{Ce}_{0.5} \mathrm{Ti}_{0.5} \mathrm{O}_{2-\delta}$, desorbed $\mathrm{CO}_{2}$ was detected at high temperature at the expense of the loss of weak basic density, and the number of strong basic sites continued to increase with increasing $x$.

3.2.5 XPS results of Ce/Ti mixed oxide catalysts. XPS analyses were performed to elucidate the transformation of chemical bonds and oxidation states on the interface of Ce-Ti composite catalysts upon doping $\mathrm{Ti}$ into $\mathrm{CeO}_{2}$. Fig. 7A shows the Ce $3 \mathrm{~d}$ spectra of all samples. Peaks $\mathrm{V}, \mathrm{V}^{\prime \prime}$ and $\mathrm{V}^{\prime \prime \prime}$ represent the Ce $3 \mathrm{~d} 5 / 2$ photoemission lines in $\mathrm{CeO}_{2}$, while the bands labeled $\mathrm{V}^{\prime}$ represent the $\mathrm{Ce}^{3+} 3 \mathrm{~d}$ final state. Lines $\mathrm{U}, \mathrm{U}^{\prime}, \mathrm{U}^{\prime \prime}$ and $\mathrm{U}^{\prime \prime \prime}$ appeared to be a result of spin-orbit splitting (Ce 3d3/2). The surface $\mathrm{Ce}^{3+}$ ratio was calculated by $\mathrm{Ce}^{3+} /\left(\mathrm{Ce}^{3+}+\mathrm{Ce}^{4+}\right)$, and results were shown in Table 2 . Surface $\mathrm{Ce}^{3+}$ ratios of $\mathrm{Ce}_{1-x} \mathrm{Ti}_{x^{-}}$ $\mathrm{O}_{2-\delta}$ samples (11.9-21.1\%) were much higher than that of pure $\mathrm{CeO}_{2}(6.5 \%)$. In general, the presence of $\mathrm{Ce}^{3+}$ was assigned to the generation of surface oxygen vacancies. Partial reduction of $\mathrm{Ce}^{4+}$ was caused by the introduction of Ti into Ce-O-Ce species to form the $\mathrm{Ti}-\mathrm{O}-\mathrm{Ce}$ structure. $\mathrm{Ce}_{0.7} \mathrm{Ti}_{0.3} \mathrm{O}_{2-\delta}$ can achieve the highest value of surface $\mathrm{Ce}^{3+}$ ratio (21.1\%) at $x=0.3$.

Fig. 7B shows the $\mathrm{O} 1 \mathrm{~s}$ spectra of the $\mathrm{Ce}_{1-x} \mathrm{Ti}_{x} \mathrm{O}_{2-\delta}$ samples. The peaks at 527-536 eV were decomposed into three components: (1) binding energy (BE) peak at $\sim 529.1 \mathrm{eV}$ corresponding to lattice oxygen $\left(\mathrm{O}_{\alpha}\right)$, (2) BE peak at $\sim 531.0-532.5 \mathrm{eV}$ corresponding to surface absorbed oxygen and surface hydroxyl groups $\left(\mathrm{O}_{\beta}\right)$, and (3) BE peak at $\sim 533.5 \mathrm{eV}$ corresponding to $-\mathrm{OH}$ species $\left(\mathrm{O}_{\gamma}\right)$ in the Ti-O-Ti bridge bonds. ${ }^{15,36-38}$ The molar ratio of $\mathrm{O}_{\beta} / \mathrm{O}_{\text {total }}$ was calculated by the area ratio of the areas under the corresponding peaks. In Table 2 , the molar ratio of $\mathrm{O}_{\beta} / \mathrm{O}_{\text {total }}$ of the $\mathrm{Ce}_{1-x} \mathrm{Ti}_{x} \mathrm{O}_{2-\delta}$ catalysts increased obviously with increasing doping ratio of $\mathrm{Ti}$, suggesting the formation of oxygen vacancies which promotes the adsorption and activation of oxygen species. In the case of the $\mathrm{Ce}_{0.3} \mathrm{Ti}_{0.7} \mathrm{O}_{2-\delta}$ catalyst, it showed a significant decrease in $\mathrm{O}_{\beta} / \mathrm{O}_{\text {total }}$ molar ratio. This is likely due to the partial deposition of $\mathrm{TiO}_{2}$ on the surface. It was also noted that the binding energy of $\mathrm{O} 1 \mathrm{~s}$ for the lattice oxygen of Ce-Ti composite oxides increased with $\mathrm{Ti}$ concentration, suggesting that $\mathrm{Ti}$ and Ce indeed react with each other to form 

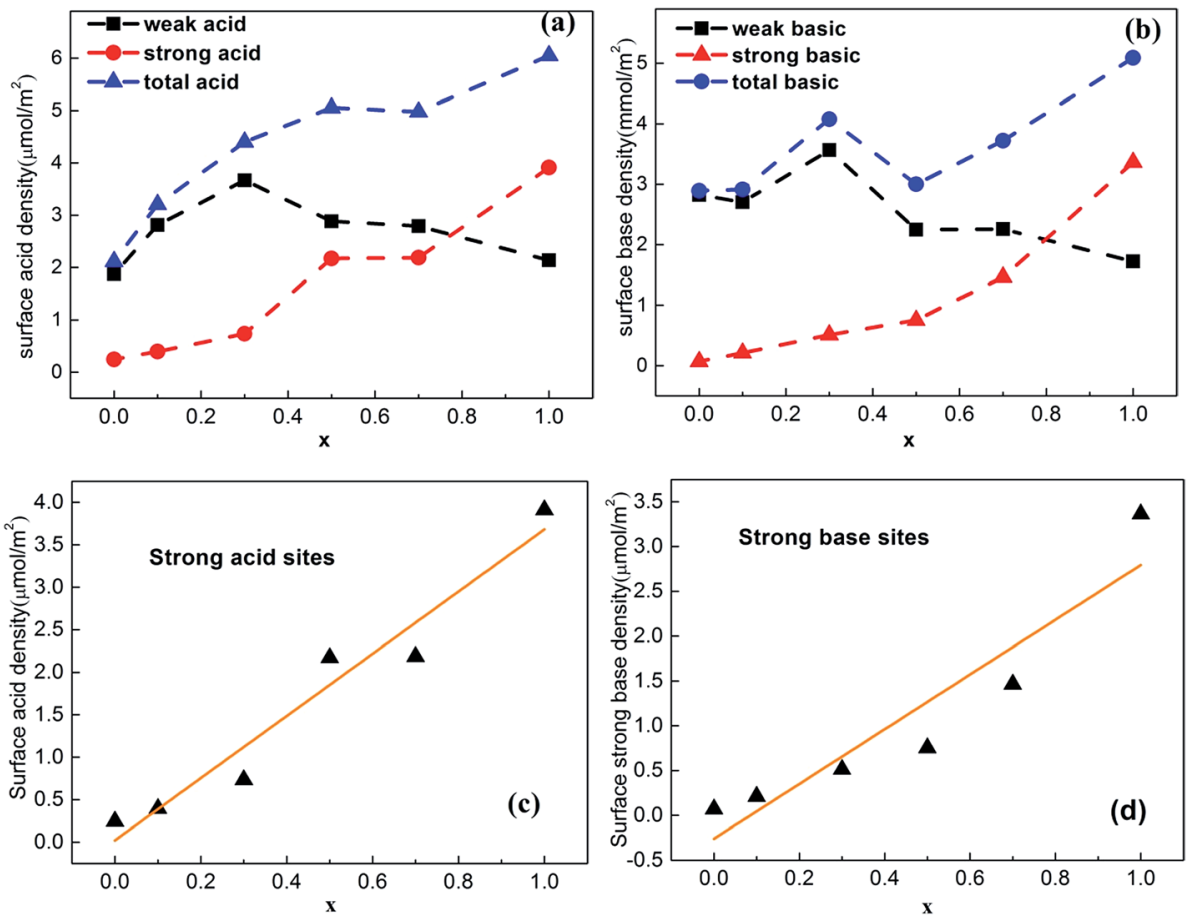

Fig. 6 Change of (a) surface acidity and (b) surface basicity of Ce-Ti with different Ce/Ti ratio, (c) and (d) linear plots of calculated surface strong acidity and basicity, respectively.
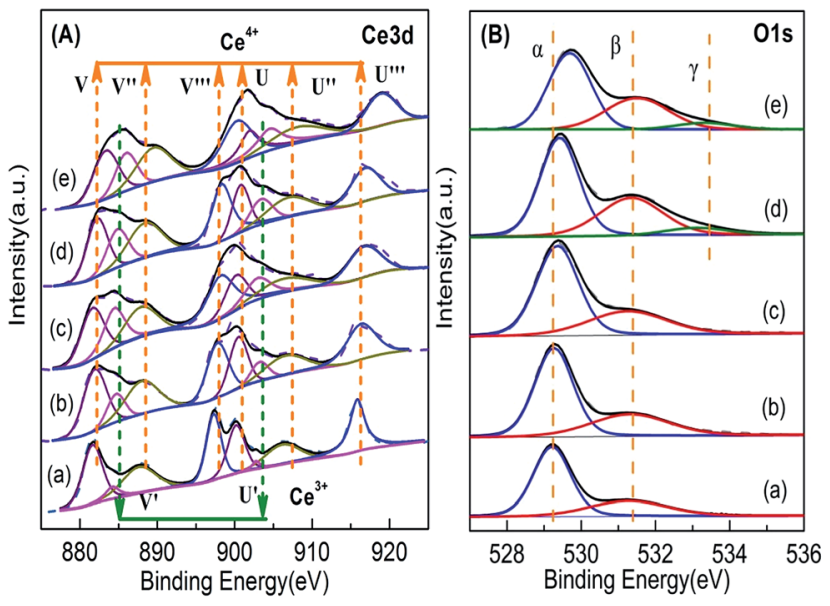

Fig. 7 XPS results of $\mathrm{Ce}_{1-x} \mathrm{Ti}_{x} \mathrm{O}_{2-\delta}$ catalysts at (a) $x=0$, (b) $x=0.1$, (c) $x=0.3$, (d) $x=0.5$, (e) $x=0.7$.

chemical bonds in composite oxides, instead of physically mixing together.

\subsection{Correlation between the reducible acid-base property and catalytic performance of $\mathrm{Ce} / \mathrm{Ti}$ mixed oxides}

As discussed above, the macro-structure of $\mathrm{Ce}_{1-x} \mathrm{Ti}_{x} \mathrm{O}_{2-\delta}$ catalysts shows a strong dependence on the doped Ti content. When the additional amount of Ti reaches a certain degree, composite oxides possess modified acid-base sites different from either pure $\mathrm{CeO}_{2}$ or $\mathrm{TiO}_{2}$, which likely results from the surface heterogeneity by substituting $\mathrm{Ce}^{4+}$ with $\mathrm{Ti}^{4+}$ ions. The macro-
Table $2 \mathrm{Ce} 3 \mathrm{~d}$ and $\mathrm{O}$ 1s XPS results of $\mathrm{Ce}_{1-x} \mathrm{Ti}_{x} \mathrm{O}_{2-\delta}$ catalysts

\begin{tabular}{|c|c|c|c|}
\hline \multirow[b]{2}{*}{$x$} & \multirow{2}{*}{$\begin{array}{l}\text { Surface } \mathrm{Ce}^{3+} \text { ratio } \\
(\%) \\
\mathrm{Ce}^{3+} /\left(\mathrm{Ce}^{4+}+\mathrm{Ce}^{3+}\right)\end{array}$} & \multicolumn{2}{|c|}{$\begin{array}{l}\text { Surface molar fraction of } \mathrm{O} \\
1 \mathrm{~s}\end{array}$} \\
\hline & & $\mathrm{O}_{\alpha} / \mathrm{O}_{\text {total }}$ & $\mathrm{O}_{\beta} / \mathrm{O}_{\text {total }}$ \\
\hline 0 & 6.5 & 0.70 & 0.30 \\
\hline 0.1 & 11.9 & 0.69 & 0.31 \\
\hline 0.3 & 21.1 & 0.66 & 0.34 \\
\hline 0.5 & 17.9 & 0.57 & 0.36 \\
\hline 0.7 & 17.3 & 0.58 & 0.32 \\
\hline
\end{tabular}

structure of the $\mathrm{Ce}_{1-x} \mathrm{Ti}_{x} \mathrm{O}_{2-\delta}$ catalysts was found to correlate with both catalytic properties (redox properties and surface acid-base density) and catalytic performance (acid conversion or ketone yield) during the ketonization reaction.

It can be seen that $\mathrm{CeO}_{2}$-rich $\mathrm{Ce}-\mathrm{Ti}$ composite oxides $(x=$ 0.1-0.5) show better ketonization reaction activity than the pure parent oxides. It was reported that carboxylic acids utilize both dehydration and dehydrogenation sites, indicating the involvement of both acid and base sites for ketonization. ${ }^{39}$ Therefore, pure $\mathrm{CeO}_{2}$ that has abundant weak basic sites but lacks acid sites, showed a lower ketonization activity compared with the $\mathrm{Ce}_{0.9} \mathrm{Ti}_{0.1} \mathrm{O}_{2}, \mathrm{Ce}_{0.7} \mathrm{Ti}_{0.3} \mathrm{O}_{2-\delta}$ and $\mathrm{Ce}_{0.5} \mathrm{Ti}_{0.5} \mathrm{O}_{2-\delta}$ samples. Furthermore, based on the ketonization mechanism with $\beta$ ketoacid as an intermediate,,$^{3,40}$ the formation of surface carboxylates was the first step. The $\alpha-\mathrm{H}$ atom was then abstracted from one carboxylate and a corresponding anionic radical was formed, while the surface $\mathrm{Ce}^{4+}$ cations were partly 
reduced by picking up the redundant electrons from the abstracted $\alpha-\mathrm{H}$ atoms. Thereafter, the anionic radical subsequently attacked another carboxylate to form the $\beta$-ketoacid intermediate. At the same time, the reduced $\mathrm{Ce}^{3+}$ cations were reoxidized by the hydroxyl radical desorbed from the intermediate. Finally, the $\beta$-ketoacid intermediate decarboxylated to form the ketone product. It should be noted that this surface mechanism involves consecutive reduction-oxidation cycles of the redox oxide catalyst. ${ }^{35,41}$ Therefore, the redox properties should play a critical role during the ketonization process. As a result, pure $\mathrm{CeO}_{2}$, which is less reducible than Ti-doped $\mathrm{CeO}_{2}$, will be restricted in taking part in the ketonization reaction.

In the case of $\mathrm{Ce}_{0.7} \mathrm{Ti}_{0.3} \mathrm{O}_{2-\delta}$, it displays the highest ketonization activity and the highest weak acid-base density. This modified surface has proper acid-base properties due to the formation of Ce-O-Ti linkage bonds. These Ce-O-Ti species are considered to be obtained via the incorporation of $\mathrm{Ti}^{4^{++}}$into the lattice of $\mathrm{CeO}_{2}$ to form a $\mathrm{CeO}_{2}$ solid solution, which has been confirmed by the results of TEM, XRD, Raman and FTIR. The redox properties of $\mathrm{Ce}-\mathrm{O}-\mathrm{Ti}$ bonds are superior to those of $\mathrm{Ce}-$ $\mathrm{O}-\mathrm{Ce}$ and $\mathrm{Ti}-\mathrm{O}-\mathrm{Ti}$ bonds, which was manifested by the fact that the $\mathrm{H}_{2}$ consumed for Ce-Ti mixed-oxides is much higher than for pure oxides. Additionally, when the Ti content is lowered to $x$ $<0.5$, the surface concentration of oxygen vacancies increases due to the formation $\mathrm{Ce}-\mathrm{O}-\mathrm{Ti}$ bonds. It is believed that the increasing amount of surface oxygen vacancies will facilitate the absorption and activation of acid molecules on the catalyst surface. ${ }^{\mathbf{4 2 - 4 4}}$ The acid consumption rate is notably increased as a function of the ratio of surface $\mathrm{Ce}^{3+}$ and the $\mathrm{Ce}_{0.7} \mathrm{Ti}_{0.3} \mathrm{O}_{2-\delta}$ catalyst with the highest surface concentration of oxygen vacancies showed the best ketonization activity. So, it gives a direct experimental proof that the presence of oxygen vacancies or coordinatively unsaturated surface metal cations could contribute to the improvement of ketonization performance at low Ti content $(x \leq 0.3)$.

$\mathrm{Ce}_{0.5} \mathrm{Ti}_{0.5} \mathrm{O}_{2-\delta}$ shows a relatively lower ketonization activity with an obvious transformation of weak acid-base sites to strong acid-base sites and inferior redox properties, compared with $\mathrm{CeO}_{2}$-like catalysts doped with $\mathrm{Ti}(x<0.5)$. This phenomenon is closely related to the change of structural properties caused by excess doped Ti. When abundant Ti is doped into $\mathrm{CeO}_{2}(x \geq 0.5), \mathrm{Ti}^{4+}$ cations will occupy interstitial sites in the fluorite lattice and/or concentrate on the oxide surface ${ }^{45}$ as confirmed by XRD, Raman, and FTIR results. The redox properties also become worse with the increased amount of doping $\mathrm{Ti}(x>0.5)$, which indicates that the interaction of $\mathrm{Ti}$ and $\mathrm{Ce}$ species becomes weaker. Moreover, the $\mathrm{Ce}_{0.3} \mathrm{Ti}_{0.7} \mathrm{O}_{2-\delta}$ sample shows a lower ketonization activity compared with the $\mathrm{Ce}_{0.5^{-}}$ $\mathrm{Ti}_{0.5} \mathrm{O}_{2-\delta}$ catalyst. This is because the worse redox ability with numerous strong acid sites for a $\mathrm{TiO}_{2}$-rich composite oxide, such as the $\mathrm{Ce}_{0.3} \mathrm{Ti}_{0.7} \mathrm{O}_{2-\delta}$ sample, will be unfavorable for the ketone formation. ${ }^{46,47}$

\subsection{Effect of co-feeding $\mathrm{CO}_{2}$ and $\mathrm{H}_{2} \mathrm{O}$}

Since both $\mathrm{CO}_{2}$ and $\mathrm{H}_{2} \mathrm{O}$ are products from the ketonization reaction, we further examined the effect of co-feeding $\mathrm{CO}_{2}$ and
$\mathrm{H}_{2} \mathrm{O}$ on the ketonization activity of the $\mathrm{Ce}_{0.7} \mathrm{Ti}_{0.3} \mathrm{O}_{2-\delta}$ catalyst. It can be seen in Fig. 8 that co-feeding of $50 \mathrm{~mol} \% \mathrm{CO}_{2}$ reduced the ketonization activity by $13 \%$ from that found without cofeeding. When terminating the co-feeding of $\mathrm{CO}_{2}$, the $\mathrm{Ce}_{0.7^{-}}$ $\mathrm{Ti}_{0.3} \mathrm{O}_{2-\delta}$ catalyst regained its ketonization activity, reaching $78 \%$. This result gives evidence that the $\mathrm{Ce}_{0.7} \mathrm{Ti}_{0.3} \mathrm{O}_{2-\delta}$ catalyst has a weak binding ability to $\mathrm{CO}_{2}$ molecules due to the lack of strong Lewis basic sites on the surface, consistent with $\mathrm{CO}_{2}$-TPD data. In parallel, co-feeding of $10 \mathrm{~mol} \% \mathrm{H}_{2} \mathrm{O}$ led to a $19 \%$ reduction in acetic acid conversion, indicating the inhibition effect of $\mathrm{H}_{2} \mathrm{O}$ on the ketonization activity. Different from the cofeeding effect of $\mathrm{CO}_{2}$, suspension of co-feeding of $\mathrm{H}_{2} \mathrm{O}$ did not recover the ketonization activity back to its initial value of $79 \%$. It should be mentioned that the calculated thermodynamic conversions of acetic acid under our conditions are $>99.8 \%$ (ref. 48 ) and it is much higher than the ones in our co-feeding test. Hence, the thermodynamic limitation impacts can be neglected here. So, the inhibition effect of water is mainly attributed to the hydrolyzation of surface intermediates, such as $\beta$-ketoacids. Besides, the adsorption of strong - $\mathrm{OH}$ groups onto the surface, which is
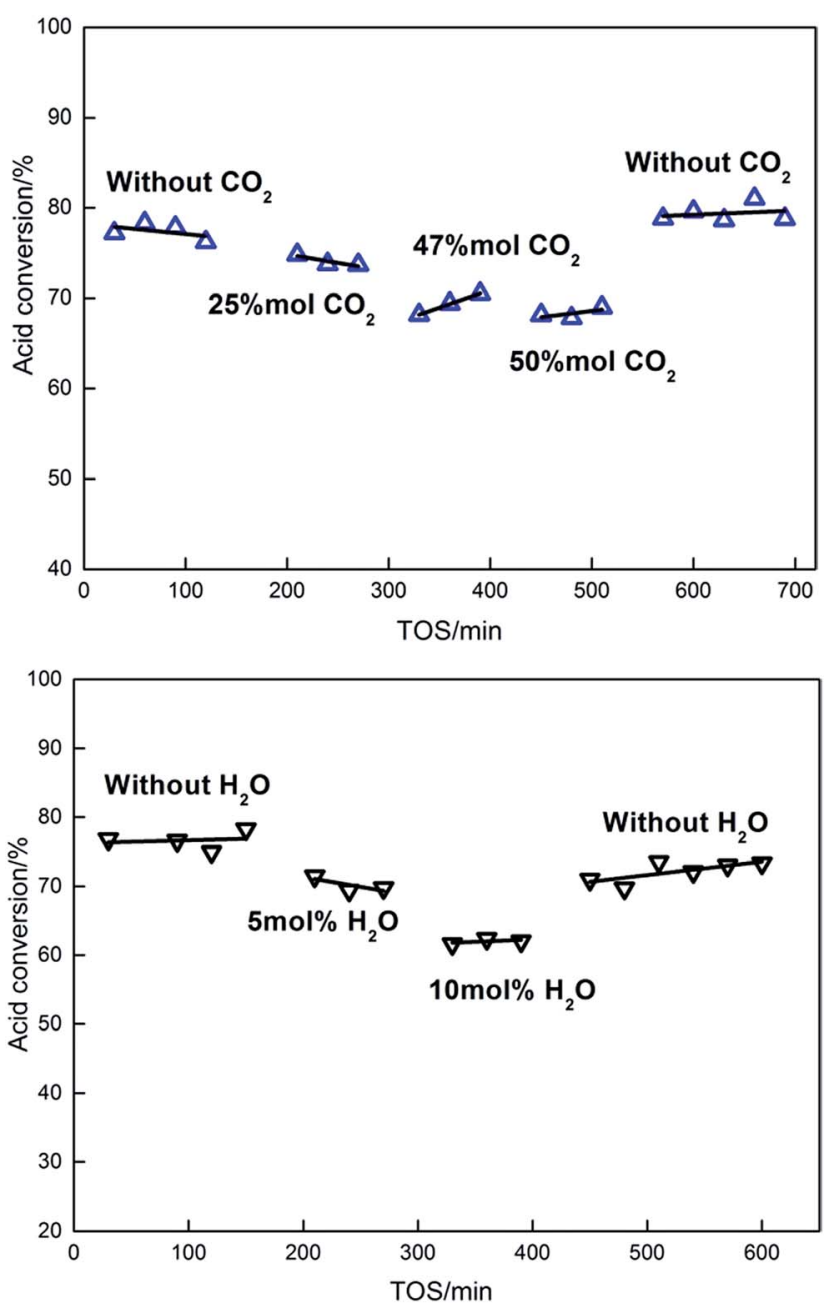

Fig. 8 Effects of $\mathrm{H}_{2} \mathrm{O}$ and $\mathrm{CO}_{2}$ in feeding (reaction conditions: $T=$

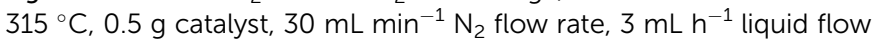
rate). 
competitive with acetic acid conversion, may also cause the decline in activity. The observation that the ketonization activity did not recover with the absence of water may be due to the modification of the surface acid-base sites, which is caused by the hydrothermal treatment to the catalysts during the reaction.,40

\subsection{Post-reaction catalyst characterization}

Both the $\mathrm{CeO}_{2}$ and $\mathrm{Ce}_{0.7} \mathrm{Ti}_{0.3} \mathrm{O}_{2-\delta}$ catalyst were characterized after $500 \mathrm{~min}$ reaction time. The XRD patterns are shown in Fig. S5. $\dagger$ It can be obviously seen that, after 500 min of ketonization reaction, both the $\mathrm{CeO}_{2}$ and Ce-Ti mixed oxide catalysts could maintain the fluorite structure with a little modification of the crystallinity. Some new diffraction peaks also appeared, which can be attributed to the formation of carboxylate. The FTIR spectra of the spent catalysts are shown in Fig. S6. $\dagger$ It is evident from the figure that the $\Delta_{\text {asy-sym }}$ was equal to 119 and $139 \mathrm{~cm}^{-1}$ for $\mathrm{CeO}_{2}$ and $\mathrm{Ce}-\mathrm{Ti}$ mixed oxides, respectively. The values imply that the surface carboxylate corresponds to a bridging or chelating coordination. ${ }^{49}$ Ce 3d XPS results (Fig. S7 $\dagger$ ) of the spent Ce-Ti catalysts also showed significant reduction of the surface cerium, which could be attributed to the presence of Ce(III) in the as-formed metal acetate. Moreover, C 1s spectra are also depicted in Fig. S7. $\dagger$ The $\mathrm{C} 1 \mathrm{~s}$ peak at $284.6 \mathrm{eV}$ is attributed to the carbon in $\mathrm{C}=\mathrm{C}$ while the $\mathrm{C} 1 \mathrm{~s}$ peak at $288.4 \mathrm{eV}$ is assigned to a carboxylate carbon. ${ }^{50}$ The $\mathrm{O} 1 \mathrm{~s}$ peak at $531.5 \mathrm{eV}$ for the spent catalyst is ascribed based on the presence of a carboxyl group $(\mathrm{O}-\mathrm{C}=\mathrm{O}) .{ }^{51}$ Both of the changes in $\mathrm{C} 1 \mathrm{~s}$ and $\mathrm{O}$ 1s spectra manifested due to the formation of surface carboxylate species. No variation of binding energies for Ti $2 p$ was observed, suggesting that $\mathrm{Ti}$ species maintained its chemical state during the ketonization. It should also be noted that the asformed metal carboxylates on the Ce-Ti catalysts can be completely decomposed thermally and restored to their original status when the spent $\mathrm{Ce}_{0.7} \mathrm{Ti}_{0.3} \mathrm{O}_{2-\delta}$ catalyst was then calcined at $450{ }^{\circ} \mathrm{C}$ in air for $1 \mathrm{~h}$ (shown in Fig. $\mathrm{S} 5 \dagger$ ).

It has been reported that the performance of the catalytic ketonization was correlated to the efficacy of forming metal acetates versus their decomposition to release a ketone. ${ }^{52}$ The as-formed surface carboxylate could facilitate the ketonization as reaction intermediates, especially at higher temperatures. As shown in the FTIR spectra, it can be seen that more surface carboxylates were formed over the Ce-Ti mixed oxides catalyst compared with pure $\mathrm{CeO}_{2}$ under the same reaction conditions. Therefore, this phenomenon indicates that the Ti-doped $\mathrm{CeO}_{2}$ with modified acid-base sites and enhanced redox properties could facilitate the formation of surface carboxylates and show better ketonization activity. Although the surface carboxylate could play the role of surface intermediates, the worse redox ability of pure $\mathrm{CeO}_{2}$ will inhibit these surface intermediates from further decomposing to products. In this case, the carboxylate may cause the deactivation.

\section{Conclusions}

In this work, we prepared a series of $\mathrm{Ce}_{1-x} \mathrm{Ti}_{x} \mathrm{O}_{2-\delta}$ mixed oxide catalysts with different doped Ti contents $(x=0.1-0.9)$ using the homogeneous precipitation method. Then, we applied these catalysts to the gas-phase ketonization reaction to produce acetone from acetic acids, with special attention to the effects of doped $\mathrm{Ti}$ contents on the ketonization activity. The $\mathrm{CeO}_{2}$-rich catalysts $(x=0.1-0.5)$ with the structure of $\mathrm{CeO}_{2}$-like solution displayed the better redox property and ketonization activity than pure metal oxides and $\mathrm{TiO}_{2}$-rich catalysts. Among the catalysts, the $\mathrm{Ce}_{0.7} \mathrm{Ti}_{0.3} \mathrm{O}_{2-\delta}$ catalyst calcinated at $500{ }^{\circ} \mathrm{C}$ exhibited the highest activity and super-stability for the ketonization reaction. This superior activity is attributed to the enhanced redox properties together with the modification of surface acid-base sites, providing by the proper formation of Ce-O-Ti linkage bonds. The excess doped Ti catalysts $(x>0.5)$ with worse redox properties and strong acid sites are unfavorable for ketone formation. Additionally, the doping of $\mathrm{Ti}$ promoted the formation of surface oxygen vacancies, which is beneficial for the ketonization reaction. This work demonstrates the promising potential of $\mathrm{Ce}-\mathrm{Ti}$ mixed oxides for practical bio-oil applications.

\section{Acknowledgements}

The authors gratefully acknowledge the support and encouragement of the National Natural Science Foundation of China (U1663222) and the National Basic Research Program of China (2012CB720500).

\section{References}

1 L. Deng, Y. Fu and Q. Guo, Energy Fuels, 2009, 23, 564-568.

2 R. Pestman, R. M. Koster, A. V. Duijne, J. Pieterse and V. Ponec, J. Catal., 1997, 168, 265-272.

3 O. Nagashima, S. Sato, R. Takahashi and T. Sodesawa, J. Mol. Catal. A: Chem., 2005, 227, 231-239.

4 Y. Kamimura, S. Sato, R. Takahashi, T. Sodesawa and T. Akashi, Appl. Catal., A, 2003, 252, 399-410.

5 C. Liu, A. M. Karim, V. M. Lebarbier, D. Mei and Y. Wang, Top. Catal., 2013, 56, 1782-1789.

6 A. D. Murkute, J. E. Jackson and D. J. Miller, J. Catal., 2011, 278, 189-199.

7 E. L. Kunkes, D. A. Simonetti, R. M. West, J. C. Serrano-Ruiz, C. A. Gärtner and J. A. Dumesic, Science, 2008, 322, 417-421.

8 C. A. Gaertner, J. C. Serrano-Ruiz, D. J. Braden and J. A. Dumesic, J. Catal., 2009, 266, 71-78.

9 S. H. Hakim, B. H. Shanks and J. A. Dumesic, Appl. Catal., B, 2013, 142, 368-376.

10 A. Gangadharan, M. Shen, T. Sooknoi, D. E. Resasco and R. G. Mallinson, Appl. Catal., A, 2010, 385, 80-91.

11 A. A. Shutilov, M. N. Simonov, Y. A. Zaytseva, G. A. Zenkovets and I. L. Simakova, Kinet. Catal., 2013, 54, 184-192.

12 Y. A. Zaytseva, V. N. Panchenko, M. N. Simonov, A. A. Shutilov, G. A. Zenkovets, M. Renz, I. L. Simakova and V. N. Parmon, Top. Catal., 2013, 56, 846-855.

13 W. Xu, Y. Yu, C. Zhang and H. He, Catal. Commun., 2008, 9, 1453-1457.

14 W. Shan, F. Liu, H. He, X. Shi and C. Zhang, ChemCatChem, 2011, 3, 1286-1289. 
15 J. Ding, Q. Zhong and S. Zhang, Ind. Eng. Chem. Res., 2015, 54, 2012-2022.

16 E. W. McFarland and H. Metiu, Chem. Rev., 2013, 113, 43914427.

17 G. Martra, Appl. Catal., A, 2000, 200, 275-285.

18 M. Luo, J. Chen, L. Chen, J. Lu, Z. Feng and C. Li, Chem. Mater., 2001, 13, 197-202.

19 W. F. Zhang, Y. L. He, M. S. Zhang, Z. Yin and Q. Chen, J. Phys. D: Appl. Phys., 2000, 33, 912.

20 C. Li and M. Li, J. Raman Spectrosc., 2002, 33, 301-308.

21 C. Liu, H. Xian, Z. Jiang, L. Wang, J. Zhang, L. Zheng, Y. Tan and X. Li, Appl. Catal., B, 2015, 176-177, 542-552.

22 X. Lu, X. Li, J. Qian, N. Miao, C. Yao and Z. Chen, J. Alloys Compd., 2016, 661, 363-371.

23 T. Tsoncheva, A. Mileva, G. Issa, M. Dimitrov, D. Kovacheva, J. Henych, N. Scotti, M. Kormunda, G. Atanasova and V. Štengl, Appl. Surf. Sci., 2017, 396, 1289-1302.

24 L. Chen, B. He, S. He, T. Wang, C. Su and Y. Jin, Powder Technol., 2012, 227, 3-8.

25 C. X. Gao, Q. F. Liu and D. S. Xue, J. Mater. Sci. Lett., 2002, 21, 1781-1783.

26 K. Nakamoto, Infrared and Raman spectra of inorganic and coordination compounds, Wiley Online Library, 1986.

27 Y. Zhang, M. Yang, X. Dou, H. He and D. Wang, Environ. Sci. Technol., 2005, 39, 7246-7253.

28 E. Aneggi, M. Boaro, C. D. Leitenburg, G. Dolcetti and A. Trovarelli, J. Alloys Compd., 2006, 408-412, 1096-1102.

29 G. Dutta, U. V. Waghmare, T. Baidya, M. S. Hegde, K. R. Priolkar and P. R. Sarode, Chem. Mater., 2006, 18, 3249-3256.

30 J. Shen, M. Tu and C. Hu, J. Solid State Chem., 1998, 137, 295301.

31 J. I. Di Cosimo, C. R. Apesteguı, A. M. J. L. Ginés and E. Iglesia, J. Catal., 2000, 190, 261-275.

32 S. Watanabe, X. Ma and C. Song, J. Phys. Chem. C, 2009, 113, 14249-14257.
33 R. W. Snell, S. H. Hakim, J. A. Dumesic and B. H. Shanks, Appl. Catal., A, 2013, 464, 288-295.

34 M. I. Zaki, M. A. Hasan, F. A. Al-Sagheer and L. Pasupulety, Colloids Surf., A, 2001, 190, 261-274.

35 M. A. Hasan, M. I. Zaki and L. Pasupulety, Appl. Catal., A, 2003, 243, 81-92.

36 M. Alifanti, B. Baps, N. Blangenois, J. Naud, P. Grange and B. Delmon, Chem. Mater., 2003, 15, 395-403.

37 S. M. Lee, H. H. Lee and S. C. Hong, Appl. Catal., A, 2014, 470, 189-198.

38 N. Yan, Z. Zhu, J. Zhang, Z. Zhao and Q. Liu, Mater. Res. Bull., 2012, 47, 1869-1873.

39 E. Iglesia, D. G. Barton, J. A. Biscardi, M. J. Gines and S. L. Soled, Catal. Today, 1997, 38, 339-360.

40 T. N. Pham, T. Sooknoi, S. P. Crossley and D. E. Resasco, ACS Catal., 2013, 3, 2456-2473.

41 T. N. Pham, D. Shi, T. Sooknoi and D. E. Resasco, J. Catal., 2012, 295, 169-178.

42 K. S. Kim and M. A. Barteau, J. Catal., 1990, 125, 353-375.

43 K. M. Dooley, A. K. Bhat, C. P. Plaisance and A. D. Roy, Appl. Catal., A, 2007, 320, 122-133.

44 S. D. Randery, J. S. Warren and K. M. Dooley, Appl. Catal., A, 2002, 226, 265-280.

45 P. L. Chen and I. W. Chen, J. Am. Ceram. Soc., 1996, 79, 17931800.

46 M. Renz, Eur. J. Org. Chem., 2005, 2005, 979-988.

47 G. Mekhemer, S. A. Halawy, M. A. Mohamed and M. I. Zaki, J. Catal., 2005, 230, 109-122.

48 T. N. Pham, D. Shi and D. E. Resasco, Top. Catal., 2014, 57, 706-714.

49 R. W. Snell and B. H. Shanks, ACS Catal., 2013, 3, 783-789.

50 J. Zhang, Y. S. Choi and B. H. Shanks, ChemSusChem, 2015, 8, 4256-4265.

51 C. H. Kim, C. Joo, H. J. Chun, B. R. Yoo, D. I. Noh and Y. B. Shim, Appl. Surf. Sci., 2012, 262, 146-152.

52 R. W. Snell and B. H. Shanks, ACS Catal., 2014, 4, 512-518. 